\title{
PTILOTUS EXTENUATUS (AMARANTHACEAE), A HITHERTO UNDESCRIBED SPECIES FROM NEW SOUTH WALES
}

\author{
G. BENL
}

(Accepted for publication 13.2.1981)

\section{ABSTRACT}

Benl, G. (Botanische Staatssammlung München, Menzinger Str. 67, D-8000 München 19, W. Germany) 1981. Ptilotus extenuatus (Amaranthaceae), a hitherto undescribed species from New South Wales.-Telopea 2 (2): 147-151, figs 1, 2.-This undescribed species collected by Charles Fraser during Oxley's New South Wales Survey Expedition 1817-18 and lodged at $\mathrm{BM}$, is described and figured below. The scanty material of a later collection-E. Officer 374 (NSW 30042)-is considered in the description.

\section{Ptilotus extenuatus Benl, sp. nov.}

Differt $a b$ aliis speciebus dissitifloris ob habitum, ob structuram distinctam spicarum et pubescentiam tepalorum diversam.

Distinguished from other species with interrupted solitary spikes primarily by its different habit and its floral features, especially the heterogeneous pubescence of the tepals.

Holotypus: New South Wales, Fraser 54, 1818 (BM); Fig. 1.

Herba tenera pilis rigidiusculis dendroideis insignis demum glabrescens. Caules nonnulli graciles (curvati-) erecti deinde plus minusve decumbentes, ad $30 \mathrm{~cm}$ et ultra longi, ad $0.2 \mathrm{~cm}$ tantum diametro, leviter ramosi; juveniles dense puberuli, denique pubescentia in partes superiores et axillas fere restricta. Folia inconspicua. Caules ramique in rachidem inflorescentiae longissime spicatae, basim versus extenuatae, plus minusve curvatae vel dependentis transeuntes. Flores summi densius collecti, inferiores singuli minores $3-10 \mathrm{~mm}$, quin etiam ad $2 \mathrm{~cm}$ remoti, bractea rigida quasi suffulti; bracteolae maiores membranaceae perianthio arcte appressae. Tepala trinervia modice carinata, marginibus scariosis limbata, apicem (sub)truncatum erosi-denticulatum versus demum aliquantum recurvata, extus pilis diversiformibus dense obtecta, basi valde indurescente ad tubum turbinatum (circa $1.5 \mathrm{~mm}$ altum) coalita. 2 exteriora ad $11 \mathrm{~mm}$ longa et $1.8 \mathrm{~mm}$ lata, extus apice glabro, intus (loco supra tubum excepto) glaberrima; 3 interiora angustiora, marginibus plus minusve involutis saepe visu acutiora, extus pilis marginalibus (praecipue in floribus juvenilibus) undulatis notata, intus inferne pilis crispis. Stamina staminodiaque 5 , in floribus examinatis 3 fertilia, basi in cupulam ad circa $2 \mathrm{~mm}$ altam extus plus minusve pilosam, tubo perianthii adnatam connata; filamenta longitudine differentia ad $8.5 \mathrm{~mm}$ longa. Ovarium subclavatum circa $3 \mathrm{~mm}$ longum (stipite $1.3 \mathrm{~mm}$ incluso) et $1 \mathrm{~mm}$ latum, imprimis apicem versus pilis strictis indutum; stylus excentricus sigmoideus; stigma inconspicuum.

An upright laxly branching herb produced from a slender fusiform tap-root (or ? rhizome). Shoots few, ephemeral, wiry, faintly ribbed, more or less curved, up to c. $30 \mathrm{~cm}$ long and $0.2 \mathrm{~cm}$ thick near ground level, simple or sparsely branched, sometimes becoming decumbent as flowers mature. Vegetative parts at first closely pubescent (less dense on foliage than on stems) with a soft white cover of minute (c. $0.2 \mathrm{~mm}$ long) intricately accumbent hairlets irregularly dendroid and substellate for the most part, intermixed with longer (to $0.8 \mathrm{~mm}$ ) projecting regularly dendroid hairs; the indumentum ultimately becoming evanescent except for apical parts of spikes and leaf axils. Leaves 1-2 cm apart, scarcely attenuated into a petiole, 
linear- to ovate-lanceolate up to $12 \times 3.5 \mathrm{~mm}$, with a visible main vein and a conspicuous pale mucro. Stems and branches merging into a more or less flexuose rachis bearing up to c. 40 single juvenile flowers and buds at intervals of 3-7 (-20) $\mathrm{mm}$; each flower subtended by a robust bract; pedicel minute, finally c. $0.7 \mathrm{~mm}$ long and jointed above the bracteoles. Terminal portion of spike with $\geqslant 20$ crowded flowers with some young leaves among them. Bract (fig. 2A) persistent, semi-rigid, lanceolate-ovate, taper-pointed (3.7-) $4.0-4.8 \mathrm{~mm}$ long, $1.5-2.0 \mathrm{~mm}$ wide; lower half dull brown hardened, the remainder membranous and narrowed towards the base; venation consisting of a midvein produced into a fine rigid awn-like point 0.7-1.7 $\mathrm{mm}$ long, and several sparingly branched nerves in the lower half of the bract; outer surface obscured by hairs as for the stem and rachis, the hairs not reaching the tip and vanishing with age; basal bracts (subtending single flowers) somewhat longer (usually c. $5 \mathrm{~mm}$ long) hardened towards the base, margins pale and mostly torn. Bracteoles (fig. 2B) subcordate-orbicular, concave, mucronate, 5.0-5.8 (-6.2) mm long, (3.6-) 3.8-4.0 mm wide, keeled with a dorsal crest in the upper portion by the dark brown prominent midrib, midrib continued into a mucro $0.8-1.1 \mathrm{~mm}$ long, the inside of the lower light-brown region with several shorter veins; the broad translucent shining wings each almost completely embracing the perianth; the central portion of the outer surface bearing (sub)dendroid hairs and the base a white tuft of shorter and denser subverticillate hairlets. Perianth elongateerect, later divergent, at length slightly recurved outward, thickened towards the narrowly turbinate hard tube c. $1.5 \mathrm{~mm}$ high, base of the perianth sunken in the concave apex of the pedicel and surrounded outside by crowded hairs c. $1 \mathrm{~mm}$ long (dendroid below, sharply verticillate in upper half). Tepals faintly keeled, limbate; inner surface showing three nerves distinct in lower portion; apices more or less truncate and irregularly toothed; margins scarious and entire, outer surface copiously invested with strong jointed hairs to $4.5 \mathrm{~mm}$ long and with an underlying series of shorter (to $1 \mathrm{~mm}$ ) delicate hairlets resembling those at the base. Outer tepals (fig. 2C) lanceolate-elliptical to -linear, (9.5-) $10.5-11 \mathrm{~mm}$ long, (1.4-) $1.6-1.8 \mathrm{~mm}$ wide when fully grown, contracted in their apical part; the apex truncate, minutely serrate, glabrous for c. $3 \mathrm{~mm}$ and exceeding the hairs inserted beneath; the long trichomes of the heterogeneous dorsal indumentum (sub)straight, patent, denticulateto verticillate-nodose; inner surface glabrous except for some simple (lacking the verticillate toothlets at the nodules) more or less crisped hairs c. $2 \mathrm{~mm}$ long arising from the upper edge of the tube; in younger stage (c. 5-6.5 $\mathrm{mm}$ long) appearing almost bottle-shaped in outline above the tube. Inner tepals (fig. 2D) narrower, 9.8-10.5 $\mathrm{mm}$ long, $1.3-1.4 \mathrm{~mm}$ wide, sometimes appearing acute owing to the infolding or incurving of margins adjacent to the apex; outer surface, especially in younger flowers, with stiff hairs restricted to the median portion, and with wavy hairs (straighter near the apex of the tepal) close to and along the margins; the outermost of the inner tepals with wavy hairs on one margin and the opposite margin bearing stiff hairs as for outer tepals, the hairs often reaching, scarcely surpassing the apex of the tepal; the lowest parts of the margins and/or the upper edge of the tube bearing crisped hairs weakly jointed and contorted between the nodes. Stamens five; fertile stamens three (in all specimens examined), filaments flattened, $6.1-8.5 \mathrm{~mm}$ long, subulate above, $0.15 \mathrm{~mm}$ wide at the middle and broadening to $0.5 \mathrm{~mm}$ at the base; staminodes $2.4-4.2 \mathrm{~mm}$ long, antherless or with a rudimentary anther; filaments and staminodes fused (their bases forming acute sinuses) into a turbinate cupula to c. $2 \mathrm{~mm}$ high (fig. 2E), firmly adnate in lower part to the perianth tube, showing a free staminal ring c. $0.5 \mathrm{~mm}$ high with flexuose hairs outside; pseudostaminodes absent. Anthers comparatively large, oblong-ellipsoid, c. $1.4-1.8 \times 0.5$ $\mathrm{mm}$. Ovary (fig. 2F) club-shaped, conspicuously stipitate when young, (2.0-) $3.0-3.2 \mathrm{~mm}$ long, $0.9-1.1 \mathrm{~mm}$ wide (including stipe c. $1.3 \mathrm{~mm}$ long), with minute dendroid to verticillate hairs c. $0.3 \mathrm{~mm}$ long, more or less biserial on the stipe and higher up, the upper part of the ovary evenly white-hirsute with straight (denticulate-) nodose hairs to $0.8 \mathrm{~mm}$ long. Style obviously eccentric, constantly sigmoid, (6.2-) $7.0(-8.2) \mathrm{mm}$ long, comparatively firm, c. $0.2 \mathrm{~mm}$ diam. in the middle, thickened to c. $0.5 \mathrm{~mm}$ at the base. Stigma inconspicuous. 


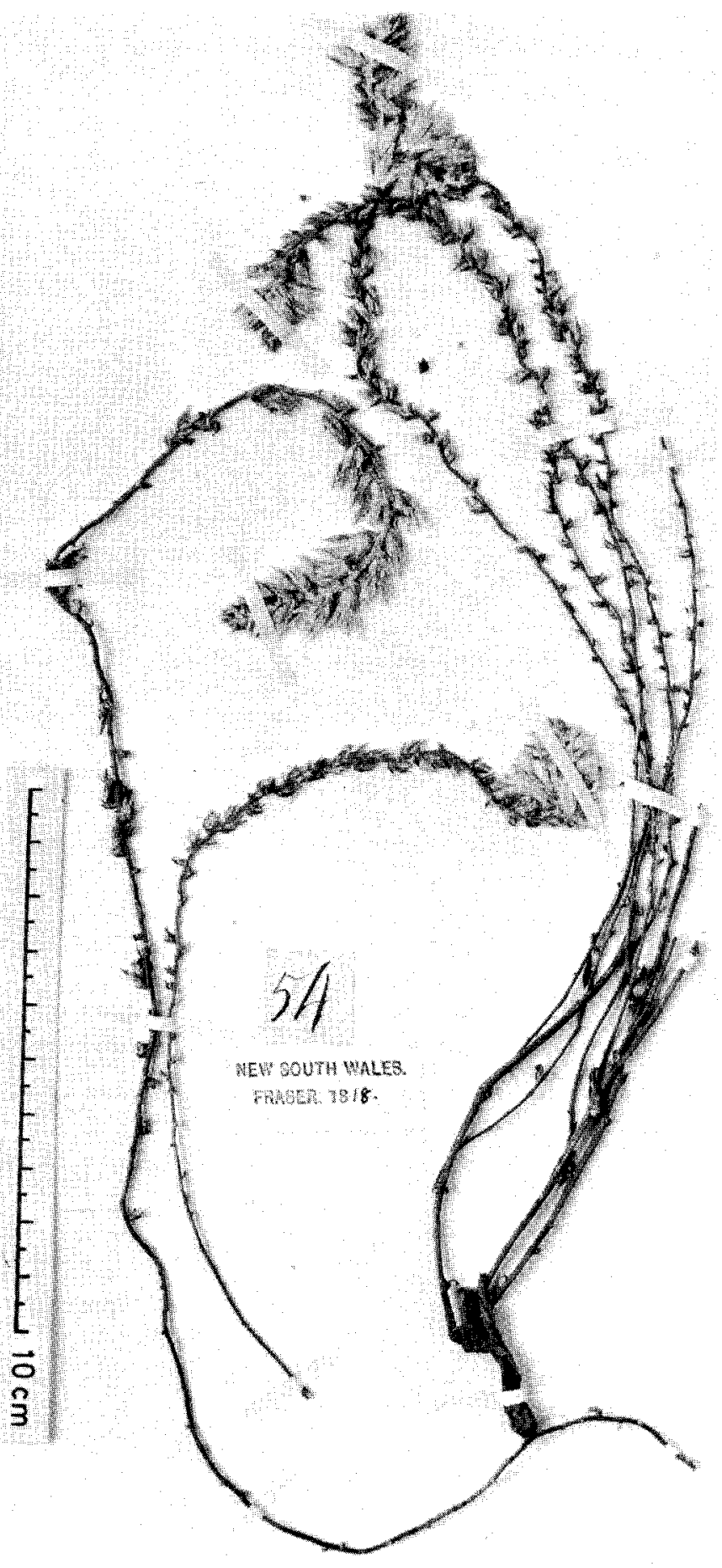

Fig. 1. Holotype: Ptilotus extenuatus Benl, sp. nov. (Fraser 54). 


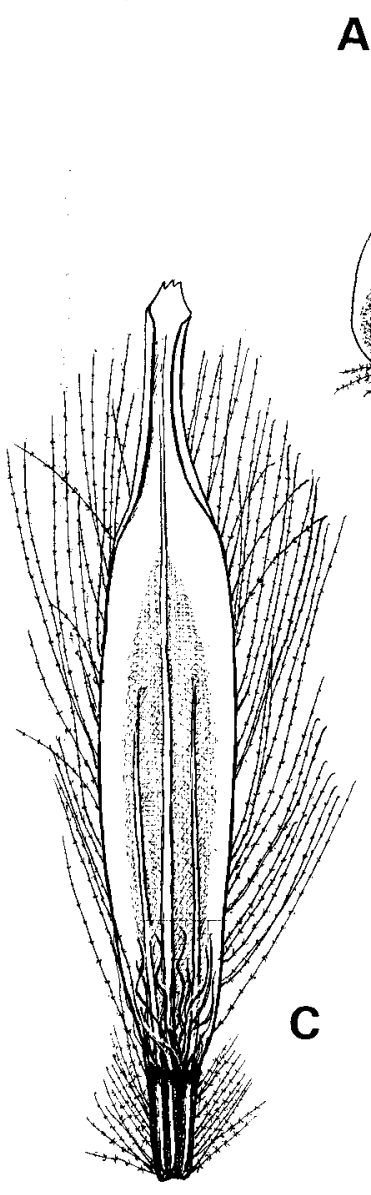

A

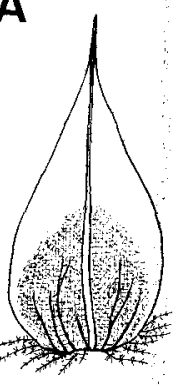

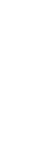
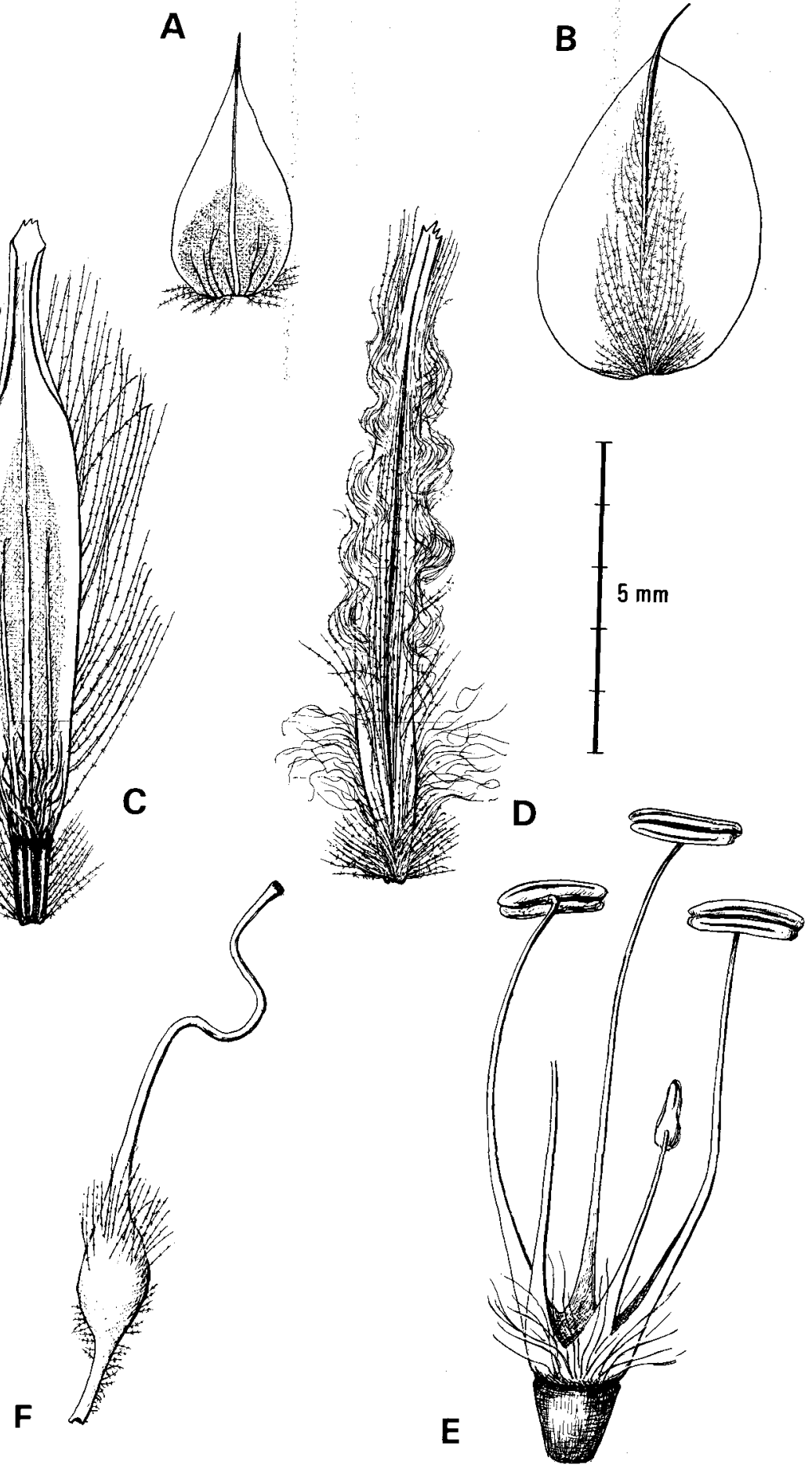

Fig. 2. Ptilotus extenuatus. A. bract, inner view. B. bracteole, outer view. C. outer tepal, inner face. D. inner tepal, outer face. E. androecium. F. gynoecium. 
Specimens Examined: New South Wales: Fraser 54, 1818 (BM); Zara, Wanganella, E. Officer 374, 12.1919 (NSW 30042).

Ptilotus extenuatus is one of a small number of species with well-spaced flowers; the other species with this feature are distinguished as follows:

$P$. distans ( $\mathrm{R}, \mathrm{Br}$.) Poir. has inferior flowers up to $2.3 \mathrm{~cm}$ apart, but glabrous stems and foliage;

$P$. royceanus Benl is a tufted shrub with inferior flowers up to $1 \mathrm{~cm}$ apart;

$P$. dissitiflorus (F. Muell.) F. Muell. is an erect loose rounded bush with inferior flowers up to $8 \mathrm{~mm}$ apart and to $2 \mathrm{~cm}$ long. (In $P$. forrestii F. Muell, and $P$. remotiflorus Benl the flowers are more crowded - c. $1 \mathrm{~mm}$ apart).

Furthermore, these other species lack such elongated spikes in which the rachis merges within the lower third of the stems and branches. P. extenuatus is the only species known to have the indumentum of the inner tepals differing from that of the outer; the inner tepals have long wavy dorsal hairs in addition to straight hairs, a condition especially evident in young flowers. These outstanding features justify recognition of the hitherto undescribed taxon as a new species.

\section{ACKNOWLEDGEMENTS}

The author wishes to express his appreciation to the Keeper of the Botany Department, British Museum (Natural History), and the Director, Royal Botanic Gardens, Sydney for arranging the loan of selected specimens. Grateful thanks are due to $\mathrm{Mr} \mathrm{A}$. Böhm for drawing the figure.

Manuscript received 4.12.1979 